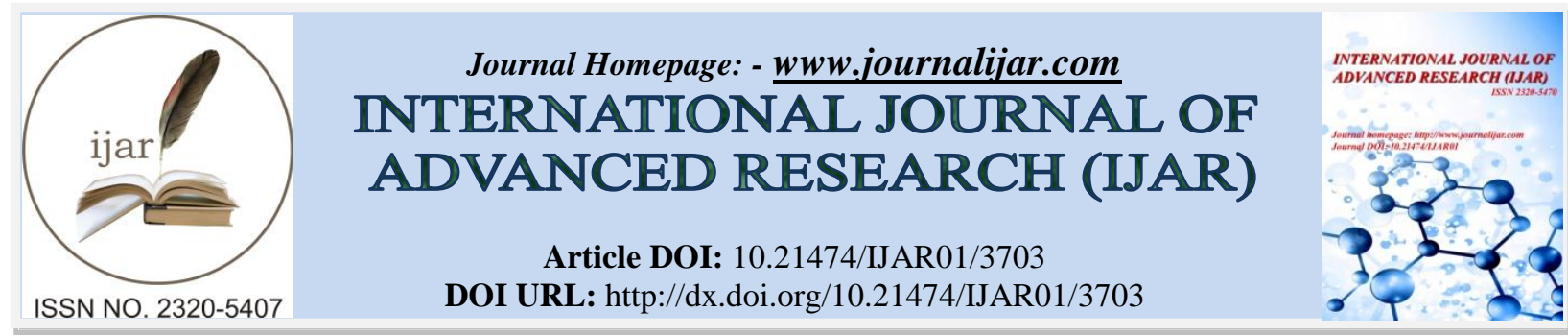

RESEARCH ARTICLE

\title{
PHARMACOVIGILANCE STUDY OF ANTIASTHMATIC AGENTS IN PATIENTS OF BRONCHIAL ASTHMA AT A TERTIARY CARE CENTRE.
}

1. Professor Pharmacology, Dr. VMGMC Solapur (MAH).

2. Postgraduate students, Dr. VMGMC Solapur (MAH).

\section{Manuscript Info}

Manuscript History

Received: 14 January 2017

Final Accepted: 08 February 2017

Published: March 2017

Key words:-

Pharmacovigilance, antiasthmatic agents,

WHO-UMC causality categories, Hartwig and

Siegel scale

\section{Abstract}

Background: Bronchial asthma is one of the most common chronic disease in the world affecting around 334 million people. Management of bronchial asthma includes multidrug therapy for long duration, which leads its association with adverse drug reactions (ADRs). Pharmacovigilance studies of antiasthmatic agents are scare in india.Therefore, the present study was planned to monitor and evaluate adverse drug reactions associated with antiasthmatic agents.

Objectives: The present study was conducted to evaluate the pattern, causality and severity analysis of adverse drug reactions associated with antiasthmatic agents in a tertiary care centre.

Materials and Methods: 150 patients of either gender, ageing above 18 years with established bronchial asthma attending outpatient and inpatient department of medicine at a tertiary care centre interviewed during the time period of October 2016 to February 2017.Central Drugs Standard Control Organisation (CDSCO) ADR forms were filled. World Health Organisation-Upasala Monitoring Centre (WHO-UMC) causality categories were used for assessment of causality. Severity of ADRs was assessed by using Hartwig and siegel scale.

Results: A total 33 ADRs were reported in 23 patients out of 150 bronchial asthma patients. Among the 23 patients reported with ADRs $10(43.47 \%)$ were male while $13(56.52 \%)$ were female. Oral thrush was most common ADR (33.33\%) followed by palpitation (15.15\%), sore throat $(12.12 \%)$, running nose, tremors (each $9.09 \%$ ), dry mouth, GI distress, bitter taste (each 6.06\%) and headache (3.03\%) among the patients of bronchial asthma receiving antiasthmatic agents. Most ADRs were associated with inhalational Beclomathasone (58.33\%) followed by inhalational budesonide (25\%), montelukast (23.07\%), salbutamol (18.75\%), theophylline (14.29\%), ipratropium (7.4\%) and salmeterol $(02.22 \%)$.

According to WHO-UMC categories $48.57 \%$ ADRs were found to be probable while $51.42 \%$ were possible. Highest percentage of ADRs $75.79 \%$ were classified as mild and $24.24 \%$ were moderate on Hartwig and Siegle scale.

Conclusion: Results of our study highlighted the need for ADR monitoring of antiasthamatics in asthma patient. Patients receiving inhalational steroids needs to be proper councelling and also written 
advice about cleansing mouth after steroid inhalation to reduce the risk of oral thrush.

Copy Right, IJAR, 2017,. All rights reserved.

\section{Introduction:-}

Bronchial Asthma is defined as reversible obstruction of airways of lungs due to its hyper-responsiveness to external or internal allergen or nonspecific stimulus like exercise, cold and characterized pathologically by chronic airway inflammation and clinically by cough, wheeze, chest tightness and dyspnoea. ${ }^{1}$ The global prevalence of asthma is anticipated to be approximately 4.5 per cent. ${ }^{2,3}$ There are about 334 million patients with asthma affecting all age groups, across the world. The prevalence of asthma has increased over the time and an additional 100 million people worldwide are expected to develop asthma by the year $2025 .^{4}$

In the Indian study on epidemiology of asthma, respiratory symptoms and chronic bronchitis in adults (INSEARCH), the prevalence of asthma in adults was 2.05 per cent, with an estimated burden of 17.23 million. ${ }^{5} \mathrm{~A}$ recent analysis using three different estimate models (INSEARCH, GINA and WHO survey) suggests that the prevalence of asthma in India varies between 2.05 to 3.5 per cent (17-30 million patients). ${ }^{6}$ India is projected to become the world's most populous nation by the year 2050. As a result, further predicted increase in the prevalence of asthma will result in a marked increase in the number of asthmatics. ${ }^{7}$

Adverse drug reaction (ADR) is associated with almost every drug ranging from mild to serious and life threatening. WHO defines ADR as "any noxious, unintended \& undesired effect to a drug that is administered in standard doses by the proper route for the purpose of prophylaxis, diagnosis or treatment". ${ }^{8}$ WHO, 2004 pioneered the concept of pharmacovigilance i.e. "Science and activities relating to the detection, assessment, understanding and prevention of ADR or any other medicine related problems". 9

ADRs constitute a considerable burden of society both financially and in terms of human suffering, and systemized ADR monitoring and reporting may sensitize physicians to rational prescribing. ${ }^{10}$

Pharmacovigilance studies for monitoring ADRs related to antiasthmatic agents have been performed by various workers around the globe. Reports on monitoring of ADRs in India are scarce. ${ }^{11}$ Oral thrush, tremor, palpitations, throat irritation and cough are common adverse effects of antiasthmatic agents. ${ }^{12}$ However causality and severity of these adverse effects remains undetected due to lack of pharmacovigilance studies in Indian context. The monitoring and evaluation of ADRs associated with antiasthmatic agents would provide the necessary information on adverse effect of different antiasthmatic agents. Therefore, the present study is planned to study the pattern of ADRs associated with antiasthmatic agents and their analysis for causality and severity in a tertiary care centre.

\section{Materials and Methods:-}

It was a non-comparative and hospital based cross-sectional questionnaire based pharmacovigilance study. The study protocol was approved by Institutional Ethics Committee. The study was carried out in outpatient and inpatient medicine department of tertiary care teaching hospital. Total 150 patients were interviewed from October 2016 to February 2017 and informed consent form was taken. All the patients of bronchial asthma, who were receiving antiasthmatics not less than 1 month were included in this study. Patients with other co-morbid conditions like hypertension, diabetes mellitus, arthritis, respiratory infections ( such as COPD, bronchitis, lung diseases ) and immunocompromised state were excluded from study.

Based on an ADR monitoring form which is drafted according to Central Drug Standard Control Organisation (CDSCO) monitoring guidelines. Demographic details (age, sex, weight) relevant medical history, present drug therapy, adverse event description, adverse event outcome and assessment information were collected. World Health Organisation-Uppsala Monitoring Centre (WHO-UMC) causality categories ${ }^{13}$ was used for assessment of causality. Severity of ADRs was assessed using Hartwig and Siegel scale. The obtained data was analyzed by using percentage method and chi square test to conclude the study results. 


\section{Results:-}

A total 33 ADRs were reported in 23 patients out of 150 bronchial asthma patients. Among the 23 patients reported with ADRs $10(43.48 \%)$ were male while $13(56.52 \%)$ were female. $8(34.78 \%)$ patients associated with ADRs observed in the age group of 41-50 years, followed by 5 (21.74\%) in age group 21-30 years, 4 (17.40\%) in age group 31-40 years, 3 (13.04\%) in age group 51- 60 and 61-70 each were observed. Distribution of ADRs among various age groups (Table 1$)$.

Oral thrush was most common adverse drug reaction (33.33\%) followed by palpitation (15.15\%), sore throat (12.13 $\%$ ), running nose, tremors (each 9.09\%), dry mouth, GI distress, bitter taste (each 6.06\%) and headache (3.03\%) among the patients of bronchial asthma receiving anti asthmatic agents (Table 2).

Most ADR was associated with inhalational Beclomathasone (58.33\%) followed by inhalational budesonide (25\%), montelukast (23.07\%), salbutamol (18.75\%), theophylline (14.29\%), ipratropium (7.4\%) and salmeterol (02.22\%) (Table3).

Among the total 23 patients, 11 were on monotherapy while 12 were on combination therapy. There was no significant difference in ADRs associated with monotherapy and combination therapy [Chi- square test, $p>0.05$ ] (Table 4).

According to WHO-UMC categories, $48.49 \%$ ADRs were found to be probable while $51.51 \%$ were possible. (Table 5).

Highest percentage of ADRs (75.76\%) were classified as mild on Hartwig and Siegel scale which included oral thrush, sore throat, running nose, dry mouth, GI distress, bitter taste, headache and were well tolerated by patients. While $24.24 \%$ were moderate which included palpitations and tremors, no severe reaction was observed (Table 6).

\section{Discussion:-}

A total 33 ADRs were reported in 23 patients out of 150 bronchial asthma patients. Among the 23 patients 10 $(43.48 \%)$ were male while $13(56.52 \%)$ were female.

Oral thrush was most commonly observed adverse drug reaction and was observed in 11 patients out of 23 (33.33 $\%$ ) who received inhalational Beclomethasone and Budesonide corticosteroids, Most ADR (oral thrush) was associated with inhalational Beclomathasone in 7 out of 11 patients $(58.33 \%)$. Oral thrush is an infection in the mouth caused by a yeast germ called, candida. Inhalational steroids may cause an overgrowth of candida which can lead to a bout of oral thrush. Cleansing mouth and brushing teeth after using the steroid inhaler may reduce the risk of oral thrush. ${ }^{14,15,16,17,18}$ All 7 patients were not rinsing mouth or brushing teeth after use of inhalation. No prior advice was given to patients regarding cleansing mouth after beclomethasone inhalation. High incidence of oral thrush in patients receiving inhalational beclomethasone is suggestive of need of counselling and advice to reduce the risk of oral thrush. There was no significant difference in ADRs associated with monotherapy and combination therapy. Highest percentage of ADRs (75.79\%) were classified as mild ADR on Hartwig and Siegel scale which included oral thrush, sore throat, running nose, dry mouth, GI distress, bitter taste, headache and were well tolerated by patients. While $24.24 \%$ were moderate which included palpitations and tremors.

\section{Conclusion:-}

Results of our study highlighted the need of ADR monitoring of antiasthamatics in asthma patient. Patients receiving inhalational steroids needs to be proper councelling and also written advice about cleansing mouth after steroid inhalation to reduce the risk of oral thrush.

Table 1:- ADRs among various age groups of asthmatic patients.

\begin{tabular}{|c|c|c|c|}
\hline AGE & MALE & FEMALE & Total (\%) \\
\hline $21-30$ & 2 & 3 & $5(21.74)$ \\
\hline $31-40$ & 2 & 2 & $4(17.40)$ \\
\hline $41-50$ & 3 & 5 & $8(34.78)$ \\
\hline $51-60$ & 2 & 1 & $3(13.04)$ \\
\hline $61-70$ & 1 & 2 & $3(13.04)$ \\
\hline
\end{tabular}


Table 2:- Types and number of Adverse Drug Reactions.

\begin{tabular}{|c|c|}
\hline Type of Adverse Drug Reaction & Number of ADRs ( Percentage ) \\
\hline Oral thrush & $11(33.33 \%)$ \\
\hline Palpitations & $5(15.15 \%)$ \\
\hline Sore throat & $4(12.13 \%)$ \\
\hline Running nose & $3(9.09 \%)$ \\
\hline Tremors & $3(9.09 \%)$ \\
\hline Dry mouth & $2(6.06 \%)$ \\
\hline GI distress, nausea & $2(6.06 \%)$ \\
\hline Bitter taste & $2(6.06 \%)$ \\
\hline Headache & $1(3.03 \%)$ \\
\hline
\end{tabular}

Table 3:- Suspected drugs and their associated type of ADRs and number.

\begin{tabular}{|c|c|c|c|}
\hline Antiasthmatic class & Drugs & $\begin{array}{c}\text { No. of ADRs/ No of } \\
\text { prescriptions } \\
\text { percentage) }\end{array}$ & ADRs (No.) \\
\hline $\boldsymbol{\beta}_{2}$ Agonist & Salbutamol & $6 / 32(18.75 \%)$ & $\begin{array}{c}\text { Palpitations (3) } \\
\text { Bitter taste (1) } \\
\text { Tremors (1) } \\
\text { Headache (1) } \\
\text { Bitter taste (1) }\end{array}$ \\
\hline Methyl Xanthines & Sheophylline & $4 / 28(14.29 \%)$ & $\begin{array}{c}\text { Palpitations (2) } \\
\text { Tremors (2) }\end{array}$ \\
\hline Corticosteroids & Beclomethasone & $7 / 12(58.33 \%)$ & $\begin{array}{c}\text { Oral thrush (5) } \\
\text { Sore throat (2) } \\
\text { Oral thrush (6) } \\
\text { Sore throat (2) }\end{array}$ \\
\hline Anti cholinergic & Budesonide & $8 / 32(25 \%)$ & $\begin{array}{c}\text { G I Distress (2) } \\
\text { Dry mouth (2) }\end{array}$ \\
\hline Leukotrine Antagonist & Ipratropium & $4 / 54(7.40 \%)$ & Running nose (3) \\
\hline
\end{tabular}

Table 4:- Number of ADRs in patients receiving mono therapy and combination therapy.

\begin{tabular}{|c|c|c|c|}
\hline Therapy & No. of Patients & No. of ADR & \multirow{3}{*}{ P $>0.05$} \\
\hline Mono therapy & 11 & 15 & \multirow{2}{*}{} \\
\hline Combination therapy & 12 & 18 & \\
\hline Total & 23 & 33 & \\
\hline
\end{tabular}

Table 5:- Causality assessment of ADRs according to WHO-UMC categories.

\begin{tabular}{|c|c|c|}
\hline Assessment & No. of ADRs & Percentage of ADRs \\
\hline Certain & 0 & 0 \\
\hline Probable & 16 & 48.49 \\
\hline Possible & 17 & 51.51 \\
\hline Unlikely & 0 & 0 \\
\hline Conditional & 0 & 0 \\
\hline Unconditional & 0 & 0 \\
\hline
\end{tabular}

Table 6:- ADR classification on basis of severity by Hartwig and Siegel scale

\begin{tabular}{|c|c|c|}
\hline Severity & No of ADRs & Percentage of ADRs \\
\hline Mild & 25 & 75.76 \\
\hline Moderate & 8 & 24.24 \\
\hline Severe & 0 & 00.00 \\
\hline
\end{tabular}




\section{References:-}

1. Peter JB. 2008. Asthma. In: Braunwald E, Frauci S, Kasper DL, Hauser SL, Lango DL, Jameson JL, editors. Harrison's principles of internal medicine. 18th ed. New York: McGraw-Hill.1596-1606.

2. Masoli M, Fabian D, Holt S, Beasley R. 2004. Global Initiative for Asthma (GINA) programme. The global burden of asthma: executive summary of the GINA Dissemination Committee report. Allergy. 59: 469-78.

3. To T, Stanojevic S, Moores G, Gershon AS, Bateman ED, Cruz AA, et al. 2012. Global asthma prevalence in adults: findings from the cross-sectional world health survey. BMC Public Health 12: 204.

4. The Global Asthma Report 2014. Auckland, New Zealand:Global Asthma Network, 2014. Available from: http://www.globalasthmareport.org/resources/Global_Asthma_Report_ 2014. pdf, [last accessed on March 13, 2017.]

5. Aggarwal AN, Chaudhry K, Chhabra SK, D'Souza GA, Gupta D, Jindal SK, et al. 2006. Prevalence and risk factors for bronchial asthma in Indian adults: a multicentre study. Indian J Chest Dis Allied Sci. 48: 13-22.

6. Agarwal R, Denning DW, Chakrabarti A. 2014. Estimation of the burden of chronic and allergic pulmonary aspergillosis in India. PLoS One. 9: e114745.

7. Murthy KJR, Sastry JG. 2005. Economic burden of asthma. In: Background Papers-Burden of disease in India. New Delhi: Ministry of Health and Family Welfare, National Commission on Macroeconomics and Health. 251-63.

8. Requirements for adverse drug reaction reporting. Geneva: 1975. WHO. 1039-109.

9. WHO policy perspective of medicines, Pharmacovigilance: 2004. Ensuring the safe use of medicines. Geneva: WHO. 1222-39.

10. Garg KC, Singhal KC, Kumar S.1993. Monitoring the adverse profile of atenolol a collaborative study. Indian J PhysiolPharmacol. 37:213-6.

11. Kallergis EM, Manios EG, Kanoupakis EM, Schiza SE, Mavrakis HE, Klapsinos NK, et al. 2005. Acute electrophysiologic effects of inhaled salbutamol in humans. Chest. 127:2057-63

12. Bajaj A, Balakrishna S, Sawarkar S. 1999. Assessment of therapeutic performances of inhalation aerosols and clinical pharmacist's services in PFT lab. Indian J Hosp Pharm. 36:138-42.

13. Uppsala Monitoring Centre(2006), the use of the World Health Organization - Uppsala Monitoring Centre(WHO-UMC) system for standardized case causality assessment.

14. NICE CKS, July 2013 (UK access only). Candida- oral.

15. Worthington HV, Clarkson JE, Khalid J, et al, Interventions for treating oral candidiasis for patients with cancer receiving treatment. Conchrane database Syst Rev. $2010 \quad$ July $7 \quad$ (7): CD001972. doi: 10.1002/1465/858. CD001972.pub 4.

16. Garcia-Cuesta C,,Sarrion-Perez MG, Bagan JV; Current treatment of oral candidiasis: A literature review. J clin Exp Dent. 2014 DEC 1 6(5) :e578-82 doi 10.4317/jced.51798. eCollection 2014 Dec.

17. Centers for Disease control and prevention.(2014). Oropharyngeal/Esopharyngeal Candidiasis ("Thrush").

18. Godara N, Godara R, Khullar M, Impact of inhalational therapy on oral health. Lung India.. 2011 Oct-Dec; 28(4): 272-75. 